Rani Shafira \& Jeane Neltje Saly

Perlindungan Hukum Bagi Pembeli Rumah Umum Dari Perbuatan Wanprestasi Oleh Developer / Pengembang

Sesuai Dengan Undang-Undang Nomor 8 Tahun 1999

Tentang Perlindungan Konsumen

\title{
PERLINDUNGAN HUKUM BAGI PEMBELI RUMAH UMUM DARI \\ PERBUATAN WANPRESTASI OLEH DEVELOPER/PENGEMBANG \\ SESUAI DENGAN UNDANG - UNDANG NOMOR 8 TAHUN 1999 TENTANG \\ PERLINDUNGAN KONSUMEN
}

\author{
Rani Shafira \\ (Mahasiswi Program S1 Fakultas Ilmu Hukum Universitas Tarumanagara) \\ (Email: Ranisafi.ranisafi@gmaail.com)

\section{Prof. Dr. Jeane Neltje Saly, S.H., M.H.} \\ (Coresponding Author) \\ (Dosen Fakultas Hukum Universitas Tarumanagara. Meraih Sarjana Hukum pada Fakultas Hukum \\ Universitas 17 Agustus Jakarta, Magister Hukum pada Fakultas Hukum Universitas Tarumanagara, \\ Doktor (Dr.) pada Fakultas Hukum Universitas Padjajaran ) \\ (Email: Jeanenovember@gmail.com)
}

\begin{abstract}
Housing or complex is a collection of houses as part of settlements, both urban and rural, equipped with infrastructure, facilities and public utilities as a result of efforts to fulfill livable houses. Nowadays housing development often happens and developers have begun to promote the building before the building was completed. Then after consumers do PPJB with the developer. But the problem that often arises is that developers have bad intentions with various things to the detriment of consumers. In this case the developer had a bad intention by guaranteeing violet garden consumer ownership certificates to Maybank to obtain a loan of funds which resulted in a loss for consumers. The problem that the author raises how is the responsibility of the developer who defaults on general home buyers according to UUPK? What is the legal protection for general home buyers from defaults carried out by developers according to UUPK? What are the obstacles and efforts of the government in implementing the UUPK against the default problems that the developer has made? The author examines this case with normative research methods. The results of the analysis obtained by the author state that the developer has defaulted on the consumer, the developer cannot be held responsible for his mistakes, the developer has violated his obligations as a business actor and the developer does not fulfill the consumer rights set out in the UUPK. Based on this case, the UUPK should be revised and consumers must be more careful in making home purchases.
\end{abstract}

Keywords: Housing, Developer, Default, Legal Protection. 


\section{PENDAHULUAN}

\section{A. Latar Belakang}

Pada era sekarang, rumah telah mengalami peralihan, tidak hanya sebagai kebutuhan dasar namun sekarang sudah menjadi keperluan yang memberikan perlindungan, namun perumahan telah menjadi gaya hidup (life style) serta memberikan kenyamanan dan menunjukkan karakter atau sifat. Di Indonesia, kebutuhan terhadap rumah mengalami peningkatan pesat, terutama pada masyarakat dikota karena jumlah penduduknya sangat banyak. Kebutuhan akan rumah juga dapat dilihat sebagai pengejawantahan dari konsitusi Indonesia khususnya pada Pasaal 28 huruf H Undangg-Undang Dasar 1945 yaitu: ${ }^{1}$

1. Tiap manusia berhak hidup sejahtera lahir dan batin, bertempat tinggal dan mendapatkan lingkungan hidup baik dan sehat serta berhak memperoleh pelayanan kesihatan.

2. Tiap manusia mendapat kemudahan dan perlayanan khusus untuk memperoleh kesempatan dan manfaat yang sama untuk mencapai persamaan dan keadilan.

3. Tiap manusia berhak atas jaminan sosial yang memungkinkan pengembangan dirinya secara keseluruhannya sebagai manusia yang bermartabat.

4. Tiap manusia berhak mempunyai hak milik pribadi dan hak milik tersebut tidak boleh direbut secara sewenang-wenang oleh siapapun.

Menurut Undang-Undangg Nomor 1 Tahun 2011 tentang Peruumahan dan Kawasan Permukimaan, Rumah ialah bangunan tempat yang digunakan sebagai tempat tinggal yang layak, sarana bimbingan family, pantulan harrkat dan martabat pemiliknya serta aset bagi pemiliknya. Perumahan/Komplek dan pemukiman selain digunakan sebagai tempat pembangunan sumber daya manusia dan penjelmaan dari lingkungan sosial yang tertib, juga merupakan sumbangan bagi

\footnotetext{
${ }^{1}$ Undang-Undangg Daasar 1945. Ketentuan Pasall $28 H$ merupakan hasil amandemeen ke-2 Undang-Undangg Dasar 1945, sebagai hasil Sidang Tahunan Majelis Permusyawaratan Rakyaat Tahan 2000 tanggal 7-8 Agustus 2000.
} 
pertumbuhan ekonomi melalui sektor industri perumahan sebagai penyediaa lapangan kerja serta mendorong pembentukan modal yang besar.

Permasalahan yang kerap muncull- dalam pemenuhan kebutuhan terhadap perumahan/komplek adalah aspek-aspek tentang konsumen dengan keberadaan konsumen berada pada posisi yang dirugikan. Berdasarkan pengaduan konsumen di BPKN, pengaduan konsumen terhadap sektor perumahan terus menerus semakin meningkat mulai dari tahun 2016 sebanyak 11\%, tahun 2017 sebanyak 8\%, tahun 2018 sebanyak 42,86\%. Mayoriitas permasalahan perumahan pada tiga tahap yaitu: Praa transaksi (perizinan, status tanah, iklan, cara menjual, klausula baku), Traansaksi (klausula baku dalam PPJB, berita acara serah terima, AJB, pertelahaan/pemisahan, sertifikat hak milik), dan Pascaa transaksi (permasalahan yang muncul adalah pengaduan konsumen/pembeli dan upaya penyelesaian sengketa masalah konsumen). ${ }^{2}$ Berbagai macam cara pembelian rumah dilakukan oleh konsumen yaitu pembelian dengan menggunakann fasilitas Kredit Pemilikan Rumah (KPR), pembelian dengan tunai keras, tunai bertahap/cash lunak dan pembelian secara kredit in-house. Pembelian secara kredit in-house merupakan suatu masalah tersendiri karena pengharapan konsumen yang besar ketika terjadinya transaksi. Konsumen sudah memberikan dana, waktu, tenaga dan pikiran agar tidak terjebak dalam memberikan putusan yang salah dan berpotensi menimbulkan kerugian. ${ }^{3}$ Keputusan dari konsumen untuk melakukan pembelian melalui skema kredit in-house memiliki resiko yang sangat besar. Upaya perlindungan bagi konsumen di Indonesia tidakk terbatas pada rendahnya kesadarann konsumen akan haknya, tetapi juga adanya persepsii yang salah dikalangann sebagian pelaku usaha bahwa perlindungan terhadap konsumen akan menimbulkan kerugian terhadap pelaku usaha. ${ }^{4}$

\footnotetext{
${ }^{2}$ Siaran pers BPKN “Marak Ketidakadilan atas Konsumen Perumahan”, www.bpkn.go.id, diakses tanggal 20 April 2019.

${ }^{3}$ Sudaryatmo, Hukum dan Advokasi Konsumen (Bandung: Citra Aditya, 1999), 46.

${ }^{4}$ Celiana Tri Siwi Kristiyanti, Op.Cit., 12.
} 
Paraa konsumen/pembeli merupakan kumpulan yang rentan dieksploitasi oleh pelaku usaha, karena itu diperlukan seperangkat aturan hukum untuk melindungi konsumen. Pihak yang memiliki kedudukan lebih baik memiliki peluang besar untuk melakukan penyalahgunaan keadaan (misbruik van omstandighegen). ${ }^{5}$ Maka dari halitu tersebut perlunya suatu peraturaan yang mengatur yaitu, perlindungan bagi konsumen/pembeli yang tidak mendapatkan haknya diatur dalam Undang-Unndang Nomor 8 Tahun 1999 tentang Peerlindungan Konsumen.

Pertimbangan atau alasan dibentuknya Undang-Undaang Nomor 8 Tahun 1999 tentang Perlindungan Konsumenn adalah bahwa pembangunan ekonomian nasional pada era globalisasi mestilah dapat mendukung tumbuhnya dunia bisnis sehingga mampu menghasilkan beraneka barang dan/atau jasa yang memiliki kandungan teknologi yang dapat mempertinggi kesejahteraan masyarakat banyak dan sekaligus mendapatkan kepastian atas barang dan/atau jasa yang diperoleh dari perdagangan tanpa mengakibatkan kerugian konsumen. ${ }^{6}$

Oleh karena hal ituu, hak-hakk bagi konsumen telah diatur dalam UUPK pasall 4 adalah sebagai berikut:

a. Hak atas kesegaran, keamanann dan bantuan dalam mengkonsumsi barang atau jasa yang dipakai

b. Hak untuk memilih atau memilah barang atau jasa serta mendapatkan barang atau jasa tersebut sesuai dengan harga dan kondisi serta jaminan yang dijanjikan;

c. Hak mendapat informasii yang benar, jelas dan jujur mengenai keadaan dan garansi barang atau jasa;

\footnotetext{
${ }^{5}$ Henry P. Panggabean, Penyalahgunaan Keadaan (Misbruik van Omstandighegen) sebagai Alasan (Baru) untuk Pembatalan Perjanjian: Berbagai Perkembanganny Hukum Di Belanda, (Yogyakarta: Kanisius, 1992), 5.

${ }^{6}$ Indonesia, Undang-Undangg Nomor 8 Tahunn 1999 tentang Perliindungan Konsumen. Konsiderans angka 2.
} 
d. Hak untuk didengarkan pendapat dan keluhannya atas barang atau jasa yang digunakan;

e. Hak untuk mendapatkan pembelaan, pengawasan dan upaya penyelesaian sengketa perlindungan konsumen secara adil;

f. Hak untuk mendapatkan pengajaran dan pengetahuan konsumen;

g. Hak untuk diperlakukan atau dilayanii secara benar dan jujur serta tidak diremehkan

h. Hak untuk mendapatkann garansi, ganti rugi/penggantian, apabila barang atau jasa yang diterima tidak sesuai dalam perjanjian;

i. Hak-hak yang diatur dalam ketentuan peraturan peruundang-undangan lainnya.

Walaupun sudah diatur hakkonsumen secara jelas dalam UUPK dan pastinya konsumen dan pelaku usaha akan menyandarkan transaksi tersebut berdasarkan perjanjiann jualbeli yang terjadi antaraa konsumen/pembeli dan pelaku usaha (developer/pengembang perumahan) dan salah satu unsur yang terdapat dalam perjanjian yaitu adanya itikad baik.

Pasal 1338 ayat (3) KUH Perdataa menyatakan bahwa "suatu perjanjian harus dilaksanakan dengan itikad baik/good intention". 7 Selain itu dalam pasal 7 huruf A UUPK mengatur kewajiban pelaku usaha dimana pelaku usaha harus beritikad baik dalam menjalankan kegiatan usahanya. Namun tetap saja di dalam prakteknya, konsumen tetap saja pihak yang dirugikan. Pada umumnya konsumen dalam melakukan pembelian perumahan tersebut kurang memperhatikan persyaratan legal dan administrasi dalam pembangunan perumahan tersebut. Konsumen tertarik pada informasi dari para marketing yang lebih menonjolkan hal-hal terkait fasilitas, letaknya yang strategis, investasi yang sangat menjanjikan karena diprediksi harga di lokasi tersebut akan terus meningkat dan tidak akan rugi dan bahkan tergiur dengan klaim bahwa dengan 3 (tiiga) tahun modal sudah dapet

\footnotetext{
${ }^{7}$ Kitab Undang-Undang Hukum Peerdata (KUH Perdata). Pasa1 1338.
} 
kembali. Selanjutnya itu, konsumen yangg telah melakukan pembayaran namun pembangunan berhenti, pembangunan perumahan tidak dilakukan hingga batas waktu penyerahan unit bahkan tidak ada pembangunan sama sekali. Hal lain yang perlu juga disorot adalah aktivitas utama pengembang (core business) yang melakukan pembangunan perumahan bukan melakukan pengelolaan pengumpulan dana masyarakat yang sebagaimana dilakukan oleh bank. Dana yang telah dibayarkan oleh konsumen kepada developer/pengembang merupakan dana yang besar minus lembaga penjamin yang menyebabkan konsumen tanpa jaminan keamanan dibangunnya rumah. Dengan adanya penelitian ini, diharapkan ditemukan solusi untuk mengatasi kerugian konsumen melakukan pembelian rumah secara Kredit Pemilikan Rumah (KPR) ataupun tunai.

Kasus yang terjadi adalah perumahan Violet Garden, konsumen yang membeli rumah dari PT. Nusuno Karya yaitu perumahan Violet Garden, kemudian cara pembeliannya melalui 2 (dua) macam pembayaran yaitu melalui tunai dengan developer/pengembang dan melalui KPR dengan Bank BRI dan BTN. Seiring berjalannya waktu pembayaran telah lunas namun, sebagian sertifikat rumah tersebut tak kunjung terbit dan sertifikat pun tidak berada di Bank yang konsumen KPR. Suatu hari ada pihak Maybank datang menemui ketua RT Perumahan Violet Garden dengan membawa surat keterangan bahwa sertifikat rumah Perumahan Violet Garden telah dijaminkan untuk pinjaman dana oleh PT. Nusuno Karya dan PT. Nusuno Karya tidak dapat melakukan pembayaran sehingga membuat pihak Maybank datang untuk memeriksa perumahan tersebut dan ternyata pihak Maybank kaget ternyata semua rumah telah ditempati oleh konsumen begitu pula dengan konsumen kaget akan hal tersebut sehingga membuat konsumen menghampiri developer/pengembang dan meminta penjelasan. Setelah diteliti oleh konsumen, ternyata developer/pengembang beritikad tidak baik dalam menjalankan kegiatan usahanya karena developer/pengembang telah menjaminkan sertifikat rumah konsumen kepada Maybank agar mendapat pinjaman dana sehingga sertifikat rumahnya di tahan di Maybank. 
Berdasarkan UUPK, konsumen berhak untuk mendapatkan hak yang seharusnya diterima dan melindungi kepentingan konsumen dalam kasus ini, yaitu mendapatkan sertifikat kepemilikan atas rumah tersebut. Pihak konsumen tidak mendapat kepastian atas rumah mereka padahal konsumen telah membayar lunas rumah tersebut dan konsumen pun tidak mendapatkan hak - hak nya sesuai perjanjian yang telah disepakati antara konsumen dan developer/pengembang. Maka saya tertarik untuk mengangkat kasus ini dengan judul "Perlindungan Hukum bagi Pembeli Rumah Umum Terhadap Wanprestasi oleh Developer/Pengembang sesuai dengan UUPK”.

\section{B. Perumusan Masalah}

Berdasarrkan uraaian latarr belakang di atas, maka penulis merumuskan masalah sebaagai beerikut:

1. Bagaimana tanggung jawab developer/pengembang yang melakukan wanprestasi terhadap pembeli rumah umum menurut UUPK?

2. Bagaimana perlindungan hukum bagi pembeli rumah umum dari wanprestasi yang dilakukan oleh developer/pengembang sesuai UUPK?

3. Bagaimana hambatan dan upaya/usaha yang dapat dilakukan oleh pemerintah dalam melaksanakan UUPK terhadap permasalahan wanprestasi yang dilakukan developer/pengembang?

\section{Metode Penelitian}

Penelitian hukum merupakan suatu kegiatan ilmiah, yang didasarkan pada metode, sistimatika dan pemikiran tertentu, yang bertujuan untuk mempelajari satusatu atau beberapa gejala hukum tentu dengan jalan menganalisanya. Kecuali itu juga diadakan pemeriksaan yang mendalam terhadap fakta hukum tersebut, untuk kemudian mengusahakan suatu pemecahan atas permasalahanpermasalahan yang timbul dalam gejala yang bersangkutan. ${ }^{8} \mathrm{Jadi}$, intinya metode penelitian hukum adalah suatu kegiatan yang didasarkan pada metode,

\footnotetext{
${ }^{8}$ Soerjono Soekanto, Op.Cit., 43.
} 
sistimatika dan pemikiran tertentu yang bertujuan untuk mempelajari satu atau beberapaa gejala hukum tertentu dalam menganalisisnya untuk memecahkan dan memberikan saran tentang apa yang seharusnya dilakukan. Oleh karena itu, untuk menjelaskan proposal penulisan ilmiah ini menggunakan metode sebagai berikut:

1. Jenis penelitian

Jenis penelitian yang digunakan dalam penelitian ini adalah penelitian hukum normatif atau disebut juga dengan penelitian untuk keperluan praktik hukum. ${ }^{9}$ Menurut Peter Mahmud Marzuki, penelitian hukum adalah suatu proses untuk menemukan aturan hukum, prinsip-prinsip hukum, maupun doktrin-doktrin hukum guna menjawab isu hukum yang dihadapi.

\section{Sifat Penelitian}

Sifat penelitian deskriptif adalah bahwa peneliti dalam menganalisis berkeinginan untuk memberikan ggambaran atau pemaparan atas subjek dan objek penelitian sebaagaimana hasil penelitian yang dilakukan.

3. Jenis Bahan Hukum

Dalam metode penelitian normatif menurut Peter Mahmud Marzuki, sumber penelitian hukum dibedakan menjadi sumber-sumber penelitian yang berupa bahan-bahann hukum primer, bahan-bahan hukum sekunder dan bahan-bahan non hukum. ${ }^{10}$

1) Bahan hukum primir merupakan bahan hukum yang bersifat otoritatif, artinya mempunyai o0toritas, yaitu merupakan hasil dari tindakan atau kegiatan yang dilakukan oleh lembaga yang

\footnotetext{
${ }^{9}$ Peter, Op.Cit., 214.

${ }^{10}$ Peter, Op.Cit., 181 .
} 
berwenang untuk itu. ${ }^{11}$ Bahan hukum primer yang digunakan dalam penulisan ini adalah: Undang- Undang Republik Indonesia Nomor 1 Tahun 2011 tentangg Perumahan dan Kawasan Permukiman, Undang-Undangg Republik Indonesia Nomor 8 Tahun 1999 tentang Perlinddungan Konsumen, Peraturan Pemerintah Republik Indonesia Nomor 14 Tahun 2016 tentang Penyelenggaraan Perumahan dan Kawasan Permukiman.

2) Bahan Bahan hukum sekunder, yaitu bahan hukum yang dapat memberikan penjelasan terhadap bahan hukum primer, yang dapat berupa rancangan perundang-undangan, hasil penelitian, buku-buku teks, jurnal ilmiah, surat kabar, brosur dan berita internet. ${ }^{12}$ Bahan hukum sekunder yang digunakan dalam penulisa ini terdiri dari: Literatur-literatur, buku-buku yang berkaitan dengan perumahan, perbankan, perjanjian, dan wanprestasi, hasil penelitian/karya ilmiah, majalah/jurnal hukum/artikel yang berkaitan dengan isu hukum yang terjadi dan bahan-bahan lainnya yang berkaitan dengan materi ditambah lagi dengan kegiatan pencarian data menggunakan internet.

3) Bahan Nonhukum adalah bahan di luar bahasan hukum yang memperkaya dan memperluas wawasan, memberikan penjelasan dan membantu dalam mengkaitkan pembahasan untuk menyelesaikan permasalahan. Bahan nonhukum yang diguanakan dalam penulisan ini yaitu: Kamus Besar Bahasa Indonesia "KBBI", kamus hukum, surat kabar dan penelurusan di internet.

4. Pendekatan Penelitian

11 Mukti Fajar dan Yulianto Achmad, Dualisme Penelitian Hukum Normatif \& Empiris, (Yogyakarta: Pustaka Pelajar, 2010), 157..

${ }^{12}$ Ibid., 158. 
Berkaitan dengan penelitian normatif, metode pendekatan penelitian yang digunakan adalah pendekatan perundang-undangan (statute approach) yang memahami hierarki dan asas-asas dalam peraturan perundang-undangan, pedekatan kasus (case approach) yang memahami dan mengerti inti permasalahannya dalam kasus. Metode ini dipilih karena merupakan pendekatan yang paling tepat dalam menjawab permasalahan dalam penulisan ini.

5. Teknik Analisis Bahan Hukum

Penelitian dalam penulisan ini menggunakan tekknik analisis bahan hukum dengan cara logika deduktif atau pengolahan bahann hukum dengan cara deduktif, yaitu menjelaskan/merumuskan suatu hal yang bersifat umum kemudian menyimpulkan menjadi kesimpulan yang lebih khusus.

\section{PEMBAHASAN}

\section{A. Tanggung Jawab Pengembang yang Melakukan Wanprestasi terhadap Pembeli Rumah Umum Menurut UUPK}

Manusia memerlukan kebutuhan demi dapat memenuhi kehidupannya hingga dapat dikatakan layak. Salah satu kebutuhan manusia yang terpenting adalah kebutuhan atas tempat tinggal dan pada saat sekarang sangat banyak developer/pengembang yang mulai membangun perumahan, rumah susun atau apartemen. Seelain itu para developer/pengembang banyak yang mulai memasarkan unit-unit tersebut bahkan sebelum bangunan tersebut selesai.

Dijelaskan bahwa dalam kasus ini developer/pengembang perumahan Violet Garden yaitu PT. Nusuno Karya telah melakukan jual beli perumahan dengan pembeli sebelum bangunan Perumahan Violet Garden selesai dibangun. Jualbeli perumahan antara pihak developerr/pengembang danm pembeli dilakukan dengan Perjanjian Pengikatan Jual Beli (PPJB) dann dilakukan pembayaran menggunakan tunai dan KPR. Dalam perjanjian tersebut 
disepakati bahwa apabila serah terima rumah kepada konsumen dilakukan maka akan diserahkan pula sertifikat kepemilikan para pembeli. Akan tetapi pada saat disepakati pihak developer/pengembang tidak menyerahkan sertifikat kepemilikan padahal para konsumen sudah membayar lunas rumah tersebut bahkan serah terima rumah sudah dilakukan. Setelah diketahui bahwa developer/pengembang telah menjaminkan sertifikat kepemilikan para pemilik rumah kepada Maybank dan telah mengalami kemacetan pembayaran. Sertifikat yang dijaminkan oleh pihak developer/pengembang sebanyak 197 sertifikat. Pihak developer/pengembang yang menjaminkan sertifikat tersebut tidak dapat melunasi pinjamannya kepada Maybank sehingga membuat pihak Maybank mendatangi konsumen yang telah menempati rumah tersebut dan Maybank pun tampak kaget ternyata perumahan tersebut telah ditempati oleh pembeli. Akibat adanya pelanggaran pada pasa1 4 Undangg-Undang Nomor 8 Tahun 1999 tentang Perlindungan Konsumen maka para konsumen yang membeli secara KPR melakukan pengaduan kepada suatu badan yang bertugas menerima laporan pengaduan mengenai perlindungan konsumen yaitu Badaan Perlindungan Konsumen Nasional (BPKN). Setelah dilakukan pemeriksaan dan analisa oleh Badan Perlindungan Konsumen Nasional maka dikeluarkan Surat Rekomendasi Nomor 2/BPKN/1/2018 tentang Rekomendasi BPKN terhadap Pengaduan Warga Perumahan Violet Garden Kranji yang isinya: Meminta Bank BTN dan Bank BRI untuk segera menghentikan sementara proses penagihan angsuran/cicilan kepada konsumen sampai adanya jaminan bahwa konsumen akan mendapat sertifikat apabila telah melunasi pembayaran KPR, meminta Bank BTN, Bank BRI dan PT. Nusuno Karya untuk segera menyelesaikan kewajibannya untuk menyerahkan dokumen sertifikat rumah konsumen Perumahan Violet Garden yang telah melunasi pembayaran KPR, Kepada seluruh konsumen Perumahan Violet Garden yang masih dalam proses pengangsuran agar menunda pembayaran kepada Bank BTN, Bank BRI dan 
PT. Nusuno Karya sampai adanya jaminan dari pihak Bank BTN, Bank BRI dan PT. Nusuno Karya mengenai keberadaan dan kepastian konsumen menerima sertifikat apabila melunasi kewajibannya. Rekomendasi yang telah diberikan oleh BPKN telah dijalankan oleh konsumen namun dari pihak-pihak Bank dan PT. Nusuno Karya belum menjalankan rekomendasi dari BPKN, maka timbul kekhawatiran dari konsumen tidak akan mendapatkan sertifikatnya sehingga konsumen yang membeli secara KPR dalam hal ini melakukan gugatan class action untuk menggugat Bank BRI dan Bank BTN karena para pemilik rumah telah membayar lunas rumah mereka, tetapi pihak Bank BRI dan Bank BTN tidak dapat memberikan sertifikat pemilik rumah tersebut. Lain halnya konsumen yang membeli secara tunai/cash dengan developer/pengembang tidak dapat menggugat developer/pengembang dikarenakan developer/pengembang sedang digugat pailit. Maka konsumen yang membeli secara tunai/cash harus menunggu sampai adanya keterangan dari pihak developer/pengembang.

Dalam Perjanjiann Pengikatan Jual Be1i (PPJB) terdapat perjanjian dalam Pasal 2 bahwanya developer/pengembang menjamin kepada konsumen bahwa sebidangg tanah berikutt bangunaan dan segala sesuatu diatasnya tidak dikenakan sitaan, adalah milik/hakknya developer/pengembang dan hanya dapat dijua1kan/dipindahkan oleh developer/pengembang dan belumm dijua1 ke pada pihak lain dan konsumen baik sekarang maupun di kemudian hari tidak akan mendapat tuntutan dari pihak 1ain yang mempunyai hak terlebih dahulu ataupun turut berhak atas sebagian dari sebidang tanah berikut bangunan dan segala sesuatu yang ada diatas tanah tersebut, tidak dijadikan jaminan untuk suatu hutang, bilamana ketentuan tersebut diatas tidak dipenuhiii oleh developer/pengembang maka ikatan untuk jua1 be1i dengan sendirinya akan jadi batal demi hukum dan dalaam hall demikian kedua belah pihak sepanjang perlu melepaskan ketentuan-ketentuan yang disebut dalam pasal1 1266 dan 
1267 KUHPerdata, sedangkan dalam hal ini developer/pengembang diwajibkan membayar kembali jumlah uang yang telah diterimanya dari konsumen dan mengganti kerugiaan yang mungkin dideritaa o1eh konsumen karena pembatalan tersebut.

Darii Perjanjian Perngikatan Jual1 Beli yang telah disepakati oleh konsumen dengan developer/pengembang dihadapan Notaris artinya developer/pengembang harus menaati perjanjian yang telah disepakati, tetapi yang terjadi developer/pengembang beritikad buruk dan telah melanggar perjanjian sesuai dengan unsur wanprestasi.

Hak para konsumen yaitu mendapatkan rumah di Perumahan Violet Garden dan sertifikat hak milik atas nama para konsumen. Kewajiban para konsumen yaitu melunasi pembayaran atas rumah di Perumahan Violet Garden secara penuh dan tanpa adanya potongan apapun, pembayaran tersebut dilakukan secara tunai/cash maupun secara KPR. Hak developer/pengembang yaitu menerima pelunasan Perumahan Violet Garden sesuai dengan kesepakatan. Kewajiban developer/pengembang yaitu menyelesaikan pembangunan Perumahan Violet Garden dan melakukan penyerahan secara fisik pada tanggal yang telah disepakati serta menyerahkan sertifikat kepemilikan rumah violet garden, begitupun menyerahkan sertifikat kepemilikan kepada Bank BRI dan BTN yang memberikan KPR kepada konsumen.

Konsumen telah melaksanakan kewajibannya menurut Pasa11 5 huruf b dan c UUPK yaitu berkewajiban untuk beritiikad baik dalam menjalankan transaksi pembelian barang dan jasa serta membayar sesuaii dengan harga yang telah disepakatin. Dalam hal ini, konsumen telah melakkukan pelunasan pembayaran untuk rumah di perumahan Violet Garden sesuai dengan yang telah disepakati oleh para pihak terkait yang melakukan perjanjian. Konsumen telah melaksanakan hak pelaku usaha menurut Pasaal 6 huruf a UUPK adalah 
kelayakan untuk menerima pembayaran sesuai dengan kesepakatan mengenai keadaan dan harga barang dan jasa yang diperdagangkan. Sedangkan pelaku usaha tidak menjalankan kewajibannya sebagaimana tercantum menurut Pasal 7 huruf a dan b UUPK yaitu harusberitikad baik dalam melakukan kegiatan usahanya serta memberikan informasi yang benar, jelas, dan jujur mengenai kondisi dan jaminan barang dan jasa, memberikan penjelasan penggunaan, perbaikan dan pemeliharaan. Pelaku usaha tidak bberitikad baik dalam menjalankan kegiatan usahanya karena sertifikat kepemilikan yang seharusnya diserahkan kepada konsumen saat pelunasan yang telah dilakukan. Dengan tindakan tersebut bahwa pelaku usaha tidak jujur dan jahat dalam menjalankan usahanya.

Terdapat 2 (dua) prinsip pentiing dalam UUPK ialah tanggung jawab produk dan tanggung jawab professional. Tanggung jawab produk (product liabillity) mengacu sebagai tanggung jawab produsen yang artinya tanggung jawab paraa produsen untuk produk yang dibawanya ke dalam penjualan, yang menimbulkan atau menyebabkan kerugian karena cacat yang melekat pada produk tersebut. Tanggung jawab dapat bersifat kontraktual (perjanjian) atau berdasarkan undang-undang. Tanggung jawab produk yang dilakukan atas pelanggaran jaminan, kelalaian, wanprestasi dan tanggung jawab mutlak.

Dalam kasus Perumahan Violet Garden pelaku usaha dapat dibebankann tanggung jawab produk karena kelengkapan fasilitas perumahan yang dijanjikan pihak developer/pengembang dalam PPJB yang telah disepakati para pihak tidak sesuai dengan seharusnya. Sedangkan, tanggung jawab professional adalah tanggung jawab hukum (legal liability) dalam hubungan dengan jasa professional yang diberikan kepada pengguna jasa. Persoalan dalam tanggung jawab dapat timbul karena para penyedia jasa professional tidak memenuhi perjanjian yang mereka sepakati dengan pengguna jasa mereka atau akibat kelalaiann penyedia jasa tersebut mengakibatkan terjadinya wanprestasi. 
Dalam kasus perumahan Violet Garden, pelaku usaha yaitu pihak developer/pengembang sebagai penyedia jasa pembangunan perumahan tidak melaksanakan tanggung jawab yang seharusnya diselesaikan sepenuhnya kepada konsumen. Pihak penyedia jasa tidak hanya harus menyelesaikan pembangunan perumahan, akan tetapi pihak tersebut juga harus menyelesaikan kelengkapan berkas-berkas sertifikat kepemilikan sebagai bukti kepemilikan para konsumen. Hal ini juga dinyatakan dalam perjanjian diantara para pihak yaitu Perjanjian Pengikatan Jual Beli (PPJB). Tanggung jawab professional mengupayakan agar kepentingan pengguna dapat di lindungi sebaik mungkin.

Dalam UUPK, Pasa1 19 ayatt (1) terdapat aturan tanggung jawab pelaku usaha ialah, memberikan gantirugi/garansi atas kerusakan, pencemaran dan/atau kerugian konsumen akibat mengkonsumsi barang dan/atau jasa yang dihasilkan atau diperdagangkan. Dijelaskan pula dalam UUPK pemberian gantirugi/garansi tidak menghapus kemungkinan adanya tunntutan pidana berdasarkan pembuktian atas unsur kesalahaan. Menurut penulis, dalam kasus Perumahan Violet Garden tanggungg jawab pelaku usaha yang diatur dalam UUPK Pasa1 19 dalam hal ini PT. Nusuno Karya sama sekali belum dijalankan, karena dalam UUPK tidak mengatur secara khusus tanggung jawab wannprestasi yang dilakukan oleh PT. Nusuno karya dan PT. Nusuno Karya saat ini sedang digugat pailit sehingga tidak dapat melaksanakan tanggung jawab ganti rugi dan tanggung jawab menebus sertifikat yang dijaminkan.

Menurut penulis, perlunya kepastian hukum untuk menentukan bahwa peraturan mengenai tanggung jaawab pelaku usaha sudah dijalankan dengana baikk atau tidak, perlunya perbaikan atau perubahan untuk peraturan tersebut agar dapat dijalankan dengan baik. Begitupun dengan tanggapan Bapak Sudikno Mertukusumo yaitu, kepastian hukum merupakan jaminan bahwa hukum tersebut dapat dija1ankan dengan baik. Sudah tentu kepastian hukum sudah menjadi bagian yang tidak terpisahkan, hal1 ini lebih diutamakan untuk 
norma hukum tertu1 is. Karena kepastian sendiri hakikatnya merupakan tujuann utama dari hukum. Kepastian hukum ini menjadi aturan masyarakat berkaitan erat dengan kepastian itu sendiri karena esensi dari aturan akan menyebabkan seseorang hidup secara berkepastian dalam melakukan kegiatan yang diper1ukan dalam melakukan aktivitas kehidupan masyarakat itu sendiri.

B. Perlindungan Hukum terhadap Konsumen dalam Pembelian Rumah Umum dari Wanprestasi yang dilakukan oleh Developer/pengembang sesuai Undang-Undang Nomor 8 Tahun 1999 tentang Perlindungan Konsumen

Perlindungan hukum merupakan salah satu hall terpenting dalam unsur suatu negara hukum. Hal itu dianggap penting karena dalam pembentukan suatu negara akan dibentuk pula norma hukum melalui peraturan perundangundangan yang mengatur setiap warga negaranya. Didalam negara akan terjadi hubungan timba1 balik antara warga negaranya sendiri. Dalam hal tersebut akan melahirkan suatu hak dan kewajiban satu sama lain. Perlindungan hukum akan menjadi hak setiap warga negaranya. Di sisi lain dapat dirasakan juga bahwa perlindungan hukum merupakan kewajiban bagi negara itu sendiri, oleh karena itu negara wajib memberikan perlindungan hukum kepada warga negaranya.

Menurut H Salim Hs Perlindungan adalah: "cara atau akal perlindungan yang diberikan o1eh hukum kepada subjek hukum serta hal-hall yang menjadi objek yang dilindungi”. Dari pandangan teori perlindungan hukum di atas tercantum berbagai unsur-unsur yaitu: Adanya wujud atau bentuk perlindungan atau tujuan perlindungan, Subjek hukum dan Objek perlindungan hukum.

Dalam setiap perundang-undangan, yang menjadi wujud atau bentuk atau tujuan perlindungan yang diberikan kepada subjek atau objek perlindungannya berbeda antara satu dengan yang lainnya. Dalam Undang-Undang Perlindungan 
Konsumen, yang menjadi tujuan hak perlindungan terhadap konsumen, yaitu menjamin terpenuhinya:

a. kelayakan untuk kenyamanan, keamanan, dan keselamatan dalam mengkonsumsi barang dan jasa;

b. kelayakan untuk memilih barang dan jasa serta mendapatkan barang dan jasa tersebut sesuai dengan harga dan kondisi serta jaminan yang dijanjikan;

c. kelayakan mendapat informasi yang benar, jelas, dan jujur mengenai kondisi dan jaminan barang dan jasa;

d. kelayakan untuk didengar pendapat dan keluhannya atas barang dan/atau jasa yang dipakai

e. kelayakan untuk mendapatkan advokasi, perlindungan, dan upaya penyelesaian sengketa perlindungan konsumen secara benar;

f. kelayakan untuk mendapat edukasi dan sosialisasi konsumen;

g. kelayakan untuk diperlakukan atau dilayani secara benar dan jujur serta tidak dirugikan;

h. kelayakan untuk mendapatkan kompensasi, ganti rugi dan penggantian, apabila barang dan jasa yang diterima tidak sesuai dengan perjanjian atau tidak sebagaimana mestinya;

i. hak-hakk yang diatur dalam ketentuan peraturan perundang-undangan lainnya.

Subjek perlindungan dalam Undang-Undag Perlindungan Konsumen adalah konsumen. objek perlindungannya, yaitu hak-hak konsumen. Kalau hakhak konsumen dilanggar, maka konsumen tersebut berhak mendapatkan perlindungan. Subjek yang berhak memberikan perlindungan pada konsumen adalah: Negara, Pemerintah, Masyarakat, Lembaga yang berwenang

Dalam hal kasus Perumahan Violet Garden, pelaku usaha te1ah me1anggar hak-haknya konsumen yang sudah diatur di UUPK Pasal 4 pelaku usaha telahh 
melakukan wanprestasi yang maksudnya tidak memenuhi perjanjian yang telah di sepakati antara konsumen dan pelaku usaha. Akan hal ini menurut penulis, konsumen sangat perlu mendapatkan perlindungan dari pihak develeoper/pengembang, dari pemerintah maupun dari negara. Sama halnya dengan yang dikatakan Bapak Benny Djaja pertama-tama menurut beliau, kita harus melihat perjanjian dalam PPJB tersebut, karena dalam Yurisprudensi telah mengatur pembeli yang beritikad baik, jika pembeli beritikad baik maka Yurisprudensi melindungi kepentingan pembeli. Yurisprudensi dibuat dalam SEMA Nomor 7 Tahun 2012 bagian IX yang berbunyi "Perlindungan harus diberikan kepada pembeli yang beritikad baik sekalipun kemudian diketahui adalah orang yang tidak berhak", Menurut penulis, PPJB telah memuat perjanjian yang telah disepakati dan developer/pengembang memang melanggar perjanjian tersebut, maka konsumen akan diberikan perlindungan sebagaimana yang disebutkan dalam SEMA. Upaya perlindungan dari Ibu Tjempaka sarankan yaitu, sebaiknya konsumen yang telah membeli secara tunai maupun kredit membuat perwakilan kelompok untuk menggugat pihak penjual (pengembang) ke peradilan umum agar para konsumen dapat mengetahui statuz kepemilikan hak atas tanah dan bangunan yang telah mereka sepakati. Seperti yang dijelaskan oleh Bapak Rizal E Halim selaku Koordinator Advokasi BPKN bahwa mereka berusaha memberikan kepastian akan di dapatnya hak-hak konsumen, dengan tetap berpegang pada kesepakatan kesepakatan yg sebelumnya, dari BPKN, paham kondisi konsumen sudah lama menunggu tapi tetep dijelaskan agar bersabar, karena proses yg di jalanin cukup berat tapi pasti konsumen akan dibantu untuk memperjuangkan hak - haknya. BPKN sendiri ingin perlindungan konsumen dilakukan dengan optimal karena punya sumber daya terbatas, konsumen terbatas otak terbatas, dana terbatas, waktu terbatas dan lainnya beda dengan pelaku usaha selalu ada upaya. Disemua Negara konsumen tidak berdaya maka negara harus membantu dan 
mewujudkan hak - haknya. Pada intinya konsumen selalu menjadi korban dan konsumen terlalu percaya pada pelaku usaha, konsumen beritikad baik harus di lindungi. Menurut penulis, konsumen selalu berkedudukan lemah, tidak berdaya, dan selalu dirugikan oleh pelaku usaha. Maka dari itu dari seluruh tanggapan dari Bapak Rizal, Bapak Benny, Ibu Tjempaka, Bapak Arif dan juga penulis peraturan mengenai Perlindungan bagi konsumen dalam UUPK haruslah ditambah, dan lebih dijelaskan mulai dari perlindungan dari developer/pengembang, perlindungan dari negara, perlindungan dari pemerintah, perlindungan terhadap hak-haknya, lebih menjelaskan perlindungan seperti apa yang akan diberikan agar konsumen tidak dirugikan. Pemerintah perlu mengeluarkan peraturan mengenai pelaku usaha dalam bidang-bidang tertentu, salah satunya dalam kasus ini yaitu bidang perumahan karena peraturan mengenai haknya, kewajibannya dan tanggung jawabnya developer/peengembang belum diatur khusus dalam Undang-Undang Nomor 8 Tahun 1999 tentang Perlindungan Konsumen maupun Undang-Undang Nomor 1 Tahun 2011 tentang Perumahan dan Kawasan Permukiman.

\section{Hambatan dan Cara Pemerintah Da1am Me1aksanakan Undang-Undang Nomor 8 Tahun 1999 tentang Perlindungan Konsumen Terhadap Permasa1ahan Wanprestasi yang Dilakukan Deve1oper/pengembang?}

Banyaknya hambatan yang terjadi untuk melaksanakan UUPK tersebut. salah satunya kasus perumahan violet garden, karena UUPK belum secara khusus mengatur sanksi-sanksi yang pantas atau sebanding dengan pelanggaran yang dilakukan developer/pengembang, belum diatur secara khusus tanggung jawab untuk developer/pengembang. Menurut penulis UUPK Pasal 19, dalam kasus Perumahan Violet Garden tanggung jawab yang dikaitkan belum jelas dan sangat luas, dalam kasus Violet Garden pelaaku usaha tidak dapat melaksanakan tanggungg jawab sesuai dengan UUPK ini, karena pelaku usaha tidak dapat membayar hutang - hutangnya sehingga tidak dapat menebus 
sertifikat milik konsumen. Dalam UUPK Pasal 31 menyatakan bahwa dalam rangka mengembangkan upaya perlindungan konsumen dibentuk Badan Perlindungan Konsumen Nasional (BPKN), dari pasal ini dapat diketahui bahwa BPKN dibentuk untuk mengembangkan upaya perlindungan konsumen khususnya tentang peraturan haknya dan kewajibannya konsumen dan pelaku usaha, peraturan larangan-larangan atau tidak boleh dilakukan bagi pelaku usaha di dalam menjalankan bisnisnya, peraturan tanggung jawab pelaku usaha dan peraturan penyelesaian sengketa perlindungan konsumen. Keempat peraturan yang disebutkan merupakan hal pokok upaya per1indungan konsumen. BPKN dibentuk agar semuanya diharapkan lebih memberdayakan konsumen dalam menuntut hak-haknya dengan tanpa mengabaikan kepentingan pelaku usaha. Pasal 33 UUPK menyatakan bahwa BPKN mempunyai fungsi memberikan saran dan pertimbangan kepada pemerintah dalam upaya mengembangkan perliindungan knsumen di Indonesia. Hambatan pemerintah dalam melaksanakan perliindungan hukum bagi konsumen yaitu, dikeluarkannya: Keputusan Menteri Negara Perumahan Rakyat No. 11/KPTS/1994 tentang Pedoman Perikatan Jual Beli Satuan Rumah Susun, dan Keputusan Menteri Negara Perumahan Rakyat No. 09/KPTS/M/1995 tentang Pedoman Perikatan Jual Beli Tanah. Seperti yang dikatakan Ibu Tjempaka, Kedua produk hukum ini direspon oleh developer/pengembang secara tidak konsisten. Pada satu sisi developer/pengembang merasa tidak terikat dengan kedua produk hukum itu dengan alasan, kedua ketentuan itu tingkatannya lebih rendah dari Undang-Undag atau Peraturann Pemerintah, dan kedua ketentuan itu hanya sekedar pedoman, sifatnya fakuktatif (kebolehan) jadi boleh diikuti boleh tidak. Maka dari itu, untuk keadilan bagi konsumen perlu upaya-upaya yang lebih dari pemerintah, negara, maupun lembaga lainnya. Menurut John Rawls, keadilan adalah memusatkan, mefokuskan, menunjukan perhatian pada distribusi hak dan kewajiban. Distribusi hak dan kewajiban harus diatur secara 
seimbang didalam masyarakat sehingga setiap orang berpeluang memperoleh manfaat dan menanggung beban yang sama.

Upaya atau cara atau akal pemerintah dalam melaksanakan perlindungan hukum bagi konsumen yaitu:

1) Peraturan Mahkamah Agung Republik 1ndonesia Nomor Tahun 2002 tentang Acara Gugatan Perwakilan Kelompok;

2) Peraturan Mahkamah Agung Republik Indonesia Nomor 1 Tahun 2006 tentang Tatacara Pengajuan Keberatan Terhadap Putusan BPSK;

3) Keputusan Presiden Nomor 37 Tahun 1994 tentang Badan Kebijaksanaan dan Pengendalian Pembangunan Perumahan dan Permukiman Nasional;

4) Peraturan Menteri Perumahan Rakyat Republik Indonesia Nomor 10 Tahun 2012 yang sudah diubah menjadi Peraturan Menteri Perumahan Rakyat Republik Indonesia Nomor 7 Tahun 2013 tentang Penyelenggaraan Perumahan dan Kawasan Permukiman dengan Hunian Berimbang;

5) OJK mengeluarkan peraturan yang disebut (PJOK) No. 1/PJOK/07/2013 tentang Perlindungan Konsumen Sektor Jasa Keuangan

Menurut penulis, upaya, cara, akal yang diberikan pemerintah sangatlah bagus, tetapi belum dijalankan dengan baik karena banyaknya Batasan-batasan yang ada dalam posisi konsumen. Saran Bapak Benny Tjaja, Undang-Undang Nomor 8 Tahun 1999 masih tertinggal dan harus dirubah, karena upaya perlindungan konsumen masih kurang, Undang-Undang Nomor 1 Tahun 2011 tentang Perumahan dan Kawasan Permukiman juga belum mengatur perliindungan, Himbawan dari BPKN tidak kuat, tidak mempunyai daya ikat, karena memang dari peraturan organisasi seperti itu hanya mengikat di dalam, 
tidak di luar siapa yang mengeluarkan izinnya maka siapa yang dapat mencabut kembali yang artinya siapa yang memberikan izin kepada developer/pengembang maka yang dapat mencabut izinnya adalah yang memberikan izin. Begitu juga dengan saran dari konsumen, berharap UUPK belum optimal dan segera dioptimalkan, dari pemerintah kurangnya bantuan, dari BPKN telah diterima atau dikirim ke pemerintah tetapi tidak ada respon.

\section{PENUTUP}

\section{A. Kesimpulan}

Salah satu kebutuhan manusia yang terpenting adalah kebutuhan atas tempat tinggal dan pada saat sekarang sangat banyak developer/pengembang yang mulai membangun perumahan, rumah susun atau apartemen. Perumahann merupakan kumpulan atau komplek rumah sebagai bagian dari permukiman, baik perkotaan maupun perdesaan, yang dilengkapi dengan prasarana, sarana, dan utilitas umum sebagai hasil upaya pemenuhan rumah yang layak huni atau layak tinggal. Pada zaman sekarang pembangunan perumahan sudah sering terjadi dan developer/pengembang sudah mulai mempromosikan bangunan tersebut sebelum bangunan itu selesai dibangun. Kemudian setelah konsumen melakukan akad yaitu PPJB dengan pihak developer/pengembang. Tetapi masalah yang sering muncul adalah developer/pengembang beritikad buruk dengan berbagai hal hingga merugikan konsumen. Dalam kasus ini developer/pengembang telah beritikad buruk dengan menjaminkan sertifikat kepemilikan para konsumen violet garden kepada Maybank untuk mendapatkan pinjaman dana dalam jumlah yang banyak sehingga mengakibatkan kerugian bagi para konsumen. Dalam kasus ini, permaslahan yang penulis angkat yaitu bagaimana tanggung jawab developer/pengembang yang melakukan wanprestasi terhadap pembeli rumah umum menurut UUPK? bagaimana perlindungan hukum bagi pembeli rumah umum dari wanprestasi yang dilakukan oleh developer/pengembang sesuai UUPK? bagaimana hambatan dan upaya pemerintah dalam melaksanakan UUPK terhadap permasalahan wanprestasi yang dilakukan developer/pengembang? 
Berdasarkan permasalahan tersebut penulis menyimpulkan bahwa developer/pengembang dalam hal ini PT. Nusuno Karya telah melanggar Perjanjian Pengikatan Jual Beli (PPJB), sudah melanggar Pasa1 4 UUPK yaitu melanggar hak-haknya konsumen, dan tidak bertanggung jawab kepada konsumen violet garden. Penulis menyimpulkan bahwa tanggung jawab developer/pengembang belum diatur khusus dalam UUPK ataupun UU Perumahan, karena dalam UUPK hanya mengatur tanggung jawab pelaku usaha secara singkat dan belum begitu jelas. Begitu juga dengan UU Perumahan sama sekali tidak mengatur mengenai developer/pengembang. tanggung jawab yang telah diatur dalam UUPK pun belum dijalankan oleh developer/pengembang karena developer/pengembang sedang menjalani persidangan PKPU yang telah digugat oleh pihak bank yang meminjamkan dana kepada developer/pengembang karena developer/pengembang tidak dapat membayar hutang-hutang tersebut. Maka penulis menyimpulkan bahwa tanggung jawab developer/pengembang, developer/pengembang harus segera menyelesaikan hutang-hutangnya dan segera menebus sertifikat rumah konsumen dan membayar semua kerugian yang telah diderita konsumen selama berusaha mendapatkan sertifikatnya kembali. Penulis menyimpulkan bahwa perlindungan hukum yang diberikan pemerintah yaitu telah dibentuk Undang-Undang Nomor 8 Tahun 1999 tentang Per1indungan Konsumen (UUPKk) Pasal 1 yang berbunyi sebagai berikut"Perlindungan Konsumen adalah segala upaya yang menjamin adanya kepastian hukum untuk memberi perlindungan kepada konsumen", dan telah dibentuk Yurisprudensi SEMA Nomor 7 Tahun 2012 bagian IX yang berbunyi "Perlindungan harus diberikan kepada pembeli yang beritikad baik sekalipun kemudian diketahui adalah orang yang tidak berhak". Namun perlindungan tersebut belum berjalan dengan baik, dan diperlukan revisi terhadap UUPK tersebut.

\section{B. Saran}


Saran dari penulis terhadap kasus Violet Garden, sebaiknya konsumen lebih teliti dalam melakukan pembelian rumah, harus memeriksa riwayat perusahaan pembangunan atau penjual rumah tersebut, harus mengerti betul mengenai akad jual beli perumahan, tata cara pembelian rumah, tata cara melakukan kredit pemilikan rumah. Jangan terlalu percaya kepada penjual maupun bank, karena sering terjadi kasus seperti ini, maka dari itu sering terjadi kasus developer/pengembang beritikad buruk. Konsumen juga harus mengetahui hakhaknya selaku pembeli, karena jika tidak mengetahui konsumen akan dirugikan terus menerus. BPKN juga harus selalu membantu konsumen baik kasus produk maupun kasus perumahan sekalipun, karena semuanya sama konsumen selalu dirugikan selalu diposisi lemah. BPKN juga harus ditingkatkan dalam memberikan saran, bisa lebih dari memberikan saran, kedepannya BPKN akan dapat memberikan perintah atau sanksi kepada pelaku usaha. UUPK harus direvisi karena banyak peraturan yang belum mengatur secara khusus mengenai pelaku usaha yang melakukan wanprestasi, pelaku usaha yang melakukan perbuatan melawan hukum dalam bidang perumahan. UU Perumahan juga harus direvisi karena peraturan khusus mengenai developer/pengembang belum diatur. Maka banyak yang harus ditingkatkan lagi. Dalam perjanjian jual beli pentingnya klausula baku, tetapi klausula baku hanya diberikan kepada konsumen maka konsumen yang sangat ditekankan, harusnya ada klausula untuk pelaku usaha agar pelaku usaha juga harus ditekan agar tidak melanggar janji. Dari hal tersebut perlunya keadilan bagi konsumen dan juga pelaku usaha sama - sama harus menepati janji yang telah dibuat oleh pihak pelaku usaha dan pihak konsumen itu

\section{DAFTAR PUSTAKA}

\section{A. Buku}

Fajar, Mukti dan Yulianti Ahmad. Dualisme Penelitian Hukum Normatif \& Empiris. Cetakan ke-1. (Jakarta: Pustaka Pelajar, 2010).

Hadjon, Philipus M. Perlindungan Hukum Bagi Rakyat Di Indonesia. (Surabaya: PT Bina Ilmu, 1987). 
dan Tatiek Sri Djatmiati. Argumentasi Hukum. (Yogyakarta: Gadjah Mada University Press, 2005).

Hamzah, Andi. et al. Dasar-Dasar Hukum Perumahan. (Jakarta: PT RINEKA CIPTA, 1990).

Harahap, M. Yahya. Segi-segi Hukum Perjanjian. (Bandung: Alumni, 1982).

Johnny, Ibrahim. Teori dan Metodologi Penelitian Hukum Normatif. (Surabaya: Bayumedia Publishing, 2005).

Kansil, C.S.T. Pengantar Ilmu Hukum dan Tata Hukum Indonesia. (Jakarta: Balai Pustaka, 1989).

Kristiyanti, Celiana Tri Siwi. Hukum Perlindungan Konsumen. Cetakan ke-3. (Jakarta: Sinar Grafika, 2011).

Marzuki, Peter Mahmud. Pengantar I1mu Hukum. (Jakarta: Kencana, 2008).

Penelitian Hukum. Cetakan ke-10. (Jakarta: Kencana Prenada Media Group, 2015).

Mertukusumo, Sudikno. Penemuan Hukum. (Yogyakarta: Liberty, 2009).

Salim HS,H. Perkembangan Hukum Jaminan Di Indonesia. (Jakarta: PT RajaGrafindo Persada, 2005). dan Erlies Septiana Nurbani. Penerapan Teori Hukum Pada Penelitian Tesis dan Disertasi. (Jakarta: PT Raja Grafindo Persada, 2013).

Santoso, Urip. Hukum Perumahan. Cetakan ke-1. (Jakarta: Kencana Prenadamedia Group, 2014).

Shofie, Yusuf. Perlindungan Hukum dan Instrumen-Instrumen Hukumnya. (Bandung: Citra Aditya Bakti, 2009).

Soedjono, Soesabdo Marmo. Peraturan Perundangan Perumahan. Cetakan ke-1. (Jakarta: Bina Aksara, 1981).

Soekanto, Soerjono. Pengantar Penelitian Hukum. Cetakan ke-3. (Jakarta: Universitas Indonesia Press, 1986). dan Yusuf Usman (ed). Perundang-undangan tentang Perumahan; inventarisasi dan analisis. Cetakan ke-l. (Jakarta: IND-HILLCO, 1987).

Subekti. Hukum perjanjian. Cetakan ke-21. (Jakarta: PT Intermasa, 2005).

Sudaryatmo. Hukum dan Advokasi Konsumen (Bandung: Citra Aditya, 1999).

\section{B. Artikel Jurnal Online}

Sukino, "Jurnal Ilmu Hukum", Perlindungan Hukum bagi Kreditur dalam Perjanjian Kredit dengan Jaminan Hak Tanggungan. Volume 5 No. 2 Februari 2015 - Ju1i 2015, 30 Maret 2019.

C. Website

Anonim, "Kredit Pemilikan rumah". www.konsumen.ojk.go.id, 27 Desember 2018.

Siaran pers, “Marak Ketidakadilan atas Konsumen Perumahan”. www.bpkn.go.id, 20 April 2019. 